\title{
PERAN INDUSTRI PENGOLAHAN TEMBAKAU DALAM PEREKONOMIAN DAN PENYERAPAN TENAGA KERJA DI KABUPATEN PONOROGO, JAWA TIMUR
}

\section{THE ROLE OF TOBACCO PROCESSING INDUSTRY TOWARD REGIONAL ECONOMY AND EMPLOYMENT IN PONOROGO REGENCY, EAST JAVA}

\author{
Dwi Rahayu Ningrum ${ }^{1 *}$, Hery Toiba ${ }^{2}$, Suhartini $^{2}$ \\ Jurusan Sosial Ekonomi, Fakultas Pertanian, Universitas Brawijaya Jl. Veteran Malang 65145, \\ Indonesia
}

Received: 19th Mei 2016; Revised: 19th Mei 2016; Accepted: 20th Mei 2016

\begin{abstract}
ABSTRAK
Tembakau adalah salah satu komoditas penting dalam perekonomian Kabupaten Ponorogo. Tembakau menjadi bahan penunjang pengembangan potensi industri pengolahan tembakau di Kabupaten Ponorogo yang terdiri dari industri rokok dan tembakau olahan. Namun demikian, pengembangan industri pengolahan tembakau saat ini harus berhadapan dengan semakin maraknya gerakan anti rokok dan peraturan pemerintah tentang perlindungan terhadap produk tembakau, yakni PP No 109 Tahun 2012. Sehubungan dengan hal tersebut, maka penelitian ini bertujuan untuk mengetahui bagaimana peran industri pengolahan tembakau, yang meliputi kontribusi sektoral, keterkaitan dan efek multiplier dalam perekonomian serta penyerapan tenaga kerja di Kabupaten Ponorogo. Metode analisis menggunakan analisis input-output dan Incremental Labor Output Ratio (ILOR). Hasil penelitian menunjukkan bahwa: 1) Industri rokok berkontribusi relatif besar pada struktur permintaan, output dan ekspor, sedangkan kontribusi industri tembakau olahan dalam perekonomian cenderung kecil; 2) Kemampuan sektor tembakau olahan dalam menarik sektor hulunya kuat, sedangkan kemampuan industri rokok dan industri tembakau olahan dalam mendorong sektor hilirnya masih lemah; 3) Sektor tembakau olahan memiliki dampak pengganda output dan pendapatan yang relatif besar. Sementara itu, industri rokok memiliki dampak pengganda tenaga kerja relatif besar; 4) Nilai ILOR industri rokok dan tembakau olahan nol. Adanya penambahan output tidak menyebabkan peningkatan ataupun penurunan penyerapan tenaga kerja karena adanya indikasi penggunaan teknologi.
\end{abstract}

Kata Kunci : tembakau; industri; rokok; input-output

\begin{abstract}
Tobacco is one of important commodity in the economy of Ponorogo regency. Tobacco becomes the supporting material for development of potential tobacco processing industry in Ponorogo regency, which consists of cigarette and processed tobacco industry. In the other hand, the development of tobacco processing industry should face the increasing of anti cigarette movement and the government's regulation about tobacco product controlling, which is PP No. 109 year 2012. Therefore, this research was conducted to analyze how is the role of tobacco processing industry covered sector's contribution, linkages, and multiplier effect in the economy, and the employment. The analysis method use input-output analysis and Incremental Labor Output Ratio (ILOR) analysis. The research result shows that: 1) The cigarette industry contribute relatively high in the structure of demand, output, and export, while the contribution of processed tobacco industry tend low; 2) The ability of processed tobacco industry to pull the downstream sector is strong, while the ability of both cigarette and processed tobacco industry to push the upstream sector is weak; 3) The processed tobacco industry has relatively high output and income multiplier, while the cigarette industry has relatively high employment multiplier; 4) The ILOR value of both cigarette and processed tobacco industry is zero. The increasing of output doesn't cause the increasing or decreasing employment because of the indication of technology use.
\end{abstract}

Keyword: tobacco; industry; cigarette; input-output 


\section{Pendahuluan}

Pemerintah Kabupaten Ponorogo memiliki beberapa perencanaan strategis pembangunan daerah, diantaranya tertuang dalam Rencana Pembangunan Jangka Menengah Daerah (RPJMD) tahun 2010-2015. Salah satu strategi pembangunan daerah Kabupaten Ponorogo adalah mewujudkan pertumbuhan ekonomi yang berkualitas dan berkelanjutan. Perwujudan strategi tersebut salah satunya adalah melalui pengembangan agroindustri dengan memperhatikan kelestarian lingkungan (Badan Perencanaan Pembangunan Daerah, 2013).

Pengembangan agroindustri dinilai tepat dilakukan mengingat pertumbuhan sektor industri pengolahan Ponorogo pada tahun 2012 yang mencapai $5,98 \%$, lebih tinggi dibandingkan sektor pertanian yang hanya mencapai $2,98 \%$. Dari tahun ke tahun nilai tambah bruto sektor ini juga mengalami peningkatan, yakni 417.086,30 juta rupiah pada tahun 2011 menjadi 466.820,55 juta rupiah pada tahun 2012 (Badan Perencanaan Pembangunan Daerah, 2013). Salah satu industri pengolahan potensial di Kabupaten Ponorogo adalah industri pengolahan tembakau yang terdiri dari industri rokok, oven tembakau, dan bumbu rokok.

Tabel 1. Jumlah Unit Usaha, Tenaga Kerja, dan Nilai Produksi Industri Pengolahan Tembakau Kabupaten Ponorogo Tahun 2012.

\begin{tabular}{clccc}
\hline No. & $\begin{array}{c}\text { Jenis } \\
\text { Industri }\end{array}$ & $\begin{array}{c}\text { Jumlah } \\
\text { usaha } \\
\text { (unit) }\end{array}$ & $\begin{array}{c}\text { Jumlah } \\
\text { tenaga } \\
\text { kerja } \\
\text { (orang) }\end{array}$ & $\begin{array}{c}\text { Nilai } \\
\text { produksi } \\
\text { (ribu } \\
\text { rupiah) }\end{array}$ \\
\hline 1. & $\begin{array}{l}\text { Oven } \\
\text { Tembakau }\end{array}$ & 42 & 450 & $3,737,110$ \\
2. & $\begin{array}{l}\text { Rokok } \\
\text { kretek }\end{array}$ & 24 & 1,144 & $16,418,111$ \\
3. & $\begin{array}{l}\text { Rokok } \\
\text { klobot }\end{array}$ & 11 & 443 & $4,636,500$ \\
$4 . \quad \begin{array}{l}\text { Bumbu } \\
\text { rokok }\end{array}$ & 5 & 45 & $1,173,300$ \\
\hline & Jumlah & 82 & 2,082 & $25,965,021$ \\
\hline
\end{tabular}

Tabel 1. menunjukkan bahwa pada tahun 2012, nilai produksi yang diciptakan oleh sektor industri pengolahan tembakau mencapai 25.96 milyar rupiah (Badan Perencanaan Pembangunan Daerah 2013). Industri pengolahan tembakau yang diusahakan meliputi industri oven tembakau, rokok kretek, rokok klobot, dan

*Penulis Korespondensi

E-mail :dwirahayun@yahoo.com@yahoo.com industri bumbu rokok. Industri rokok kretek tercatat memberikan kontribusi nilai produksi terbesar pada sektor ini, yakni mencapai 16.42 milyar rupiah.

Saat ini keberadaan rokok sebagai produk olahan tembakau mulai ditentang oleh masyarakat. Hal ini karena mulai tingginya kesadaran masyarakat tentang kerugian yang ditimbulkan oleh konsumsi rokok, khususnya gangguan kesehatan berupa kanker, penyakit paru-paru, tekanan darah tinggi, dsb. Adanya masyarakat yang menentang keberadaan rokok ini semakin diperkuat dengan ratifikasi hukum internasional Konvensi Kerangka Pengendalian Tembakau atau Framework Convention on Tobacco Control (FCTC) pada Februari 2005. Peraturan ini bertujuan untuk melindungi generasi sekarang dan mendatang dari konsekuensi kesehatan, sosial, lingkungan, dan ekonomi karena konsumsi tembakau dan paparan asap rokok.

Pemerintah juga telah mengeluarkan peraturan terkait perlindungan terhadap produk tembakau dan zat adiktif lain, yakni Peraturan Presiden No 109 Tahun 2012. Peraturan ini dikhawatirkan akan mengancam keberlangsungan industri pengolahan tembakau terutama rokok. Industri rokok yang masih berskala kecil dan menengah serta berbasis kerakyatan seperti di Kabupaten Ponorogo dapat mengalami kerugian bahkan gulung tikar karena adanya penurunan konsumsi rokok oleh masyarakat akibat peraturan tersebut. Tidak hanya industri rokok yang akan mengalami dampak negatif tetapi juga sektor pertanian tembakau sebagai penyedia utama input produksi rokok.

Fenomena industri pengolahan tembakau tersebut menjadi menarik untuk dikaji bagaimana perannya dalam perekonomian yang dihadapkan pada isu kesehatan, khususnya di Kabupaten Ponorogo. Penelitian sebelumnya mengenai peran tembakau dalam perekonomian dilakukan oleh Hadi dan Friyatno (2008) pada tingkatan nasional. Berbeda dengan penelitian sebelumnya, ruang lingkup penelitan ini lebih sempit, yakni pada tingkatan kabupaten. Pendekatan yang digunakan dalam penelitian ini sama dengan penelitian sebelumnya, yakni analisis input output. Pada penelitian ini selain menggunakan analisis input output juga menggunakan analisis Incremental Labour Ouput Ratio (ILOR) sebagai analisis tambahan untuk mengetahui bagaimana kemampuan industri pengolahan tembakau dalam menyerap tenaga kerja dengan adanya penambahan output. 
Tujuan dalam penelitian ini adalah: 1) Menganalisis kontribusi sektor industri pengolahan tembakau terhadap perekonomian dilihat dari pembentukan permintaan, output sektoral, nilai tambah bruto, ekspor-impor, dan ketengakerjaan; 2) Menganalisis peran industri pengolahan tembakau dilihat dari keterkaitannya dengan sektor perekonomian lain baik keterkaitan ke depan maupun ke belakang; 3) Menganalisis dampak ekonomi industri pengolahan tembakau terhadap sektor-sektor perekonomian lain dilihat dari angka pengganda output, pendapatan, dan tenaga kerja; dan 4) Menganalisis seberapa besar industri pengolahan tembakau mampu menyediakan kesempatan kerja berdasarkan pertambahan output sektor industri pengolahan tembakau.

\section{Metode Penelitian}

Penentuan lokasi penelitian dilakukan secara purposive, yakni Kabupaten Ponorogo, Jawa Timur dengan pertimbangan adanya potensi industri pengolahan tembakau. Penelitian dilakukan pada bulan April hingga Juni 2014. Data yang digunakan dalam penelitian adalah data sekunder yang diperoleh dari Badan Pusat Statistik, Dinas Perindustrian dan Perdagangan, serta Kantor Badan Perencanaan Pembangunan Daerah Kabupaten Ponorogo. Data digunakan untuk menurunkan Tabel Input Output (IO) Ponorogo 2011, adalah Tabel IO Jawa Timur 2010 updating 2011, PDRB Kabupaten Ponorogo 2011 dan 2012, dan Ponorogo dalam Angka 2008-2012.

Data penelitian dianalisis dengan analisis input output dan Incremental Labor Output Ratio (ILOR). Pengolahan data untuk keperluan analisis input-output ataupun ILOR dilakukan dengan menggunakan software Microsoft Excell.

Langkah pertama untuk analisis input output adalah membuat Tabel Input Output Kabupaten Ponorogo tahun 2011 dengan cara menurunkannya dari Tabel Input Output Jawa Timur updating tahun 2011. Derivasi tabel IO dilakukan dengan metode RAS untuk mendapatkan kuadran input antara yang baru. Metode RAS dilakukan tidak hanya untuk menyesuaikan matriks koefisien lintas waktu (updating), tetapi juga lintas ruang atau derivasi (Miller dan Blair, 1985). Metode RAS adalah suatu rumus matriks, yaitu:

$\mathrm{A}(\mathrm{t}) \quad=\mathrm{RA}(0) \mathrm{S}$
Dimana:

A(t) : matriks koefisien input tahun 2011 Kabupaten Ponorogo

A(0) : matriks koefisien input tahun 2011 Jawa Timur

$\mathrm{R}$ : matriks diagonal yang menunjukkan pengganda menurut baris

$\mathrm{S}$ : matriks diagonal yang menunjukkan pengganda menurut kolom

a. Analisis Kontribusi Industri Pengolahan Tembakau dalam Perekonomian Kabupaten Ponorogo

Tujuan pertama penelitian, dianalisis secara deskriptif. Deskripsi ini dapat dilakukan dengan melihat secara langsung data yang tersedia pada Tabel Input-Output Kabupaten Ponorogo Tahun 2011 klasifikasi 64 sektor. Penggambaran kontribusi industri pengolahan tembakau, meliputi peran dalam pembentukan permintaan, output, nilai tambah bruto, eksporimpor, pendapatan, dan ketenagakerjaan. Kontribusi tersebut diperoleh dengan persentasenilai masing-masing sektor dengan total sektor pada setiap komponen perekonomian.

b. Analisis Peran Industri Pengolahan
Tembakau dalam Perekonomian
Kabupaten Ponorogo Dilihat dari
Keterkaitan ke Depan dan ke Belakang

Analisis ini dilakukan untuk menjawab tujuan kedua penelitian. Analisis keterkaitan meliputi analisis keterkaitan langsung ke depan dan ke belakang. Perhitungan analisis keterkaitan dilakukan sebagai berikut (Nazara, 2005):

1). Keterkaitan langsung ke depan, yang dihitung dengan rumus sebagai berikut:

$K L D i=\frac{\sum_{j=1}^{64} X_{i}}{X_{i}}=\sum_{j=1}^{64} a_{i j}$

Dimana:

$\mathrm{KLD}_{\mathrm{i}}$ : keterkaitan langsung ke depan industri rokok dan tembakau olahan

$\mathrm{X}_{\mathrm{i}}$ : output industri rokok dan tembakau olahan yang digunakan sebagai input antara sektor $\mathrm{j}$

Xi : total output industri rokok dan tembakau olahan

$\mathrm{a}_{\mathrm{ij}} \quad$ : unsur matriks koefisien teknis

2). Keterkaitan langsung ke belakang yang dihitung dengan rumus: 


$$
K L B j=\frac{\sum_{i=1}^{64} X_{j}}{X_{j}}=\sum_{i=1}^{64} a_{i j}
$$

Dimana:

$\mathrm{KLB}_{\mathrm{j}}$ : keterkaitan langsung ke depan industri rokok dan tembakau olahan

$\mathrm{X}_{\mathrm{i}} \quad$ : input antara yang digunakan industri rokok dan tembakau olahan yang berasal dari sektor i

$\mathrm{Xi}$ : total input industri rokok dan tembakau olahan

$a_{i j} \quad$ : unsur matriks koefisien teknis

3). Koefisien Penyebaran, dihitung dengan menggunakan rumus sebagai berikut (Nazara, 2005):

$$
B d_{j}=\frac{\sum_{i=1}^{64} a_{i j}}{\sum_{i=1}^{64} a_{i j} \sum_{i=1}^{64} a_{i j}}
$$

Dimana:

$\mathrm{Bd}_{\mathrm{j}}$ : koefisien penyebaran sektor industri pengolahan tembakau

$\mathrm{a}_{\mathrm{ij}} \quad$ : unsur matriks kebalikan Leontief

4). Kepekaan Penyebaran, yang dihitung dengan rumus sebagai berikut:

$$
F d_{i}=\frac{\sum_{j=1}^{64} a_{i j}}{\sum_{j=1}^{64} a_{i j} \sum_{j=1}^{64} a_{i j}}
$$

Dimana:

$\mathrm{Fd}_{\mathrm{j}}$ : derajat kepekaan sektor industri pengolahan tembakau

$\mathrm{a}_{\mathrm{ij}} \quad$ : unsur matriks kebalikan Leontief

c. Analisis Dampak Ekonomi Industri Pengolahan Tembakau Terhadap SektorSektor Perekonomian Lain di Kabupaten Ponorogo.

Analisis ini dilakukan untuk menjawab tujuan ketiga penelitian. Analisis angka pengganda terdiri dari tiga, yakni angka pengganda output, pendapatan, dan tenaga kerja (Nazara, 2005).

1). Angka Pengganda (Multiplier) Output Untuk menghitung pengganda output menggunakan rumus (Nazara, 2005):

$O_{j}=\sum_{i=1}^{64} C_{i j}$

Dimana:

$\mathrm{O}_{\mathrm{j}} \quad$ : multiplier output
$\mathrm{C}_{\mathrm{ij}} \quad$ : unsur matriks kebalikan Leontif terbuka

2). Angka Pengganda (Multiplier) Pendapatan

Perhitungan pengganda pendapatan dilakukan dengan menggunakan rumus sebagai berikut (Nazara, 2005):

$Y_{j}=\frac{\sum_{i=1}^{64} a_{n+1, j} C_{i j}}{a_{n+1, j}}$

Dimana:

$\mathrm{Y}_{\mathrm{j}} \quad$ : multiplier pendapatan

$\mathrm{C}_{\mathrm{ij}} \quad$ : unsur matriks kebalikan Leontif terbuka

$A_{n+1, j}$ : koefisien input gaji / upah rumah tangga sektor perekonomian

3). Angka Pengganda (Multiplier) Tenaga Kerja

Pengganda tenaga kerja dapat diketahui dengan menghitungnya menggunakan rumus sebagai berikut (Nazara, 2005):

$W_{j}=\frac{\sum_{i=1}^{64} w_{n+1, j} C_{i j}}{w_{n+1, j}}$

Dimana:

$\mathrm{Y}_{\mathrm{j}} \quad$ : multiplier tenaga kerja

$\mathrm{C}_{\mathrm{ij}} \quad$ : unsur matriks kebalikan Leontif terbuka

$A_{n+1, j}$ : koefisien tenaga kerja sektor perekonomian

d. Analisis Incremental Labor Output Ratio (ILOR)

Analisis ini dilakukan untuk menjawab tujuan keempat penelitian. ILOR merupakan rasio tenaga kerja output marginal sebagai koefisien yang menghubungkan penambahan tenaga kerja ( $\mathrm{L}$ ) terhadap kenaikan output atau produk yang dihasilkan ( Y). Rumus perhitungan ILOR dalam Susanto dan Jatmiko (2011) adalah sebagai berikut:

$I L O R=\frac{\Delta L}{\Delta \mathrm{Y}}$

Keterangan :

ILOR : Incremental Labor Output Ratio (Tahun 2012)

$\mathrm{L}$ : penambahan tenaga kerja sektor industry rokok dan tembakau olahan

Y : penambahan output (nilai PDRB)

\section{Hasil dan Pembahasan}

\subsection{Kontribusi Industri Pengolahan Tembakau dalam Perekonomian Kabupaten Ponorogo}


Kontribusi sektor perekonomian Kabupaten Ponorogo, khususnya sektor industri rokok, tembakau olahan, dan pertanian tembakau dilihat dari kontrirbusi dalam struktur permintaan, output, ekspor-impor, nilai tambah bruto, dan ketenagakerjaan. Struktur permintaan tersusun atas permintaan antara dan permintaan akhir. Permintaan antara adalah keseluruhan permintaan dari sektor produksi yang digunakan untuk kegiatan produksi. Permintaan antara berupa input produksi yang dibutuhkan oleh sektor produksi. Sementara itu, permintaan akhir merupakan permintaan konsumen akhir domestik (Ningsih, 2001).

Sektor pertanian tembakau berada pada peringkat ke-52 dalam struktur permintaan Kabupaten Ponorogo dengan nilai mencapai 9.265,61 juta rupiah. Sebesar $66,66 \%$ total permintaan pertanian tembakau digunakan untuk memenuhi permintaan antara sektor lain sebagai input produksi, sisanya sebesar 33,34\% dialokasikan untuk permintaan akhir. Sektor industri rokok berada pada peringkat ke- 6 dengan total permintaan $\mathrm{Rp} 526.061,63$ juta rupiah. Sebagian besar output sektor industri rokok lebih banyak dialokasikan untuk permintaan akhir, seperti pemenuhan konsumsi rumah tangga ataupun ekspor daripada menjadi input produksi. Sementara itu, industri tembakau olahan berada pada peringkat ke-50 dengan total permintaan mencapai $10.274,79$ juta rupiah. Nilai permintaan akhir tembakau olahan yang lebih besar dibandingkan dengan permintaan antara menunjukkan bahwa kebanyakan output dari industri tembakau olahan dialokasikan untuk memenuhi permintaan akhir.

Struktur output Kabupaten Ponorogo tersusun atas nilai produksi barang dan jasa yang dihasilkan oleh masing-masing sektor perekonomian di wilayah tersebut. Output yang termasuk dalam Tabel IO Ponorogo 2011 hanya output yang dihasilkan oleh daerah tersebut. Hal ini karena Tabel IO yang digunakan adalah tabel transaksi domestik atas harga produsen, sehingga impor diperlakukan sebagai non kompetitif (Ningsih, 2001). Pada tahun 2011, total output yang terbentuk mencapai 11.901.228,55 juta rupiah. Sektor pertanian tembakau berkontribusi sebesar 0,078\% atau sebesar 9.265,61 juta rupiah. Industri rokok berkontribusi sebesar $4,42 \%$ terhadap pembentukan output total atau senilai 526.061,64 juta rupiah. Sementara itu, sektor tembakau olahan berkontribusi sebesar 0,086\% atau senilai 10.274.79 juta rupiah. Sektor ini berada pada peringkat ke-50 pembentukan output domestik Ponorogo.

Kontribusi terhadap struktur nilai tambah bruto dapat dilihat dari komponen pembentuk NTB dan kontribusi NTB per sektor. Total nilai tambah bruto Kabupaten Ponorogo pada tahun 2011 mencapai 8.404.945,13 juta rupiah. Salah satu komponen pembentuk nilai tambah bruto terbesar adalah surplus usaha senilai 4.715.830,40 juta rupiah $(56,09 \%)$. Upah dan gaji berkontribusi sebesar $36,38 \%$ atau senilai 3.058.479,83 juta rupiah. Sementara itu, kontribusi penyusutan mencapai $4,56 \%$ atau sebesar 383.056,38 juta rupiah dan pajak tidak langsung berkontribusi sebesar $2,97 \%$ atau 250.051,98 juta rupiah.

Apabila dilihat dari sektor pembentuknya, sektor pertanian tembakau berada pada peringkat ke-22 dari keseluruhan sektor perekonomian. Sektor ini berkontribusi pada pembentukan nilai tambah bruto sebesar 75.822,46 juta rupiah $(0,902 \%)$. Sektor industri rokok sendiri berkontribusi senilai $83.579,98$ juta rupiah atau sebesar $0,99 \%$, tidak berbeda jauh dengan sektor pertanian tembakau dengan berada pada peringkat ke-20. Sementara itu, sektor industri tembakau olahan berkontribusi sebesar 382,21 juta rupiah atau $0,005 \%$.

Pada struktur ekspor dan impor, yang dimaksud adalah keseluruhan transaksi ekonomi barang dan jasa yang dilakukan oleh penduduk Kabupaten Ponorogo dan bukan penduduk Kabupaten Ponorogo, baik antar kabupaten atau provinsi. Total nilai ekspor Kabupaten Ponorogo pada tahun 2011 adalah senilai 772.767,39 juta rupiah. Industri rokok memiliki kontribusi ekspor terbesar dengan nilai ekspor mencapai $104.143,32$ juta rupiah atau $13,48 \%$. Nilai ekspor yang tinggi dari industri rokok mengindikasikan output industri rokok banyak dialokasikan untuk memenuhi konsumsi rokok di luar Kabupaten Ponorogo. Sektor pertanian tembakau berkontribusi pada struktur ekspor sebesar $2.696,38$ juta rupiah atau $0,35 \%$ dari total ekspor. Sementara itu, sektor tembakau olahan memiliki nilai ekspor yang lebih kecil dibandingkan dengan sektor pertanian tembakau, yakni sebesar $1.544,34$ juta rupiah atau $0,20 \%$. Sama halnya dengan sektor tembakau, nilai ekspor tersebut menunjukkan output industri tembakau olahan lebih banyak dialokasikan untuk memenuhi kebutuhan input produksi sektor perekonomian lain.

Total nilai impor Kabupaten Ponorogo tahun 2011 mencapai 1.158.095,19 juta rupiah. 
Industri rokok sebagai sektor yang mendominasi ekspor ternyata juga melakukan transaksi impor. Tercatat transaksi impor sektor ini mencapai $11.274,76$ juta rupiah atau sebesar $0,974 \%$. Sama halnya dengan sektor industri rokok, sektor pertanian tembakau dan industri tembakau olahan juga melakukan transaksi impor. Sektor tembakau ternyata memiliki nilai impor yang lebih tinggi dibandingkan dengan nilai ekspor. Nilai impor sektor ini mencapai 4.171,99 juta rupiah atau berkontribusi sebesar $0,36 \%$ dari keseluruhan nilai impor. Sedangkan sektor industri tembakau olahan nilai impornya mencapai 1.226,91 juta rupiah atau sebesar $0,106 \%$.

Kemampuan suatu sektor perekonomian dalam menciptakan kesempatan kerja terlihat dari seberapa besar jumlah tenaga kerja yang dapat terserap pada sektor. Sektor-sektor perekonomian Kabupaten Ponorogo pada tahun 2011 mampu menyerap tenaga kerja sebanyak 451.450 orang. Pada tahun 2011, sektor pertanian tembakau menyerap tenaga kerja sejumlah 1.604 orang atau $0,36 \%$. Selanjutnya, sektor industri rokok sebagai sektor hilir dari pertanian tembakau berkontribusi dalam penyerapan tenaga kerja sejumlah 1.286 orang atau $0,28 \%$. Sedangkan sektor industri tembakau olahan mampu menyerap tenaga kerja sebanyak 641 orang atau dengan persentase $0,14 \%$ dari total penduduk bekerja.

Struktur ketenagakerjaan di Kabupaten Ponorogo juga dilihat dari bagaimana produktivitas, rasio upah dan koefisien tenaga kerja untuk keseluruhan sektor perekonomian (Fahriyah, 2006). Sektor pertanian tembakau memiliki tingkat produktivitas lebih rendah bila dibandingkan dengan sektor industri rokok. Sektor pertanian tembakau memiliki nilai produktivitas sebesar Rp47,26 juta/TK, yang berarti bahwa setiap satu tenaga kerja mampu menciptakan nilai tambah bruto senilai 47,26 juta rupiah per tahun, Tingkat produktivitas sektor industri rokok mencapai Rp 64,97 juta/TK, Sementara itu, pada industri tembakau olahan, tingkat produktivitasnya masih rendah, yakni hanya mencapai Rp0,60 juta/TK yang berarti setiap tenaga kerja hanya mampu menciptakan nilai tambah sebesar 0,60 juta rupiah per tahun.

Tingkat upah pada sektor pertanian tembakau menunjukkan angka yang lebih tinggi dibandingkan dengan sektor industri rokok dan industri tembakau olahan. Rasio upah tenaga kerja pada sektor pertanian tembakau adalah sebesar 15,38 yang berarti bahwa dalam satu tahun tingkat upah tenaga kerja yang bekerja pada sektor ini adalah 15,38 juta rupiah. Tingkat upah industri rokok adalah 10,06 menunjukkan bahwa tingkat upah tenaga kerja adalah 10,06 juta rupiah untuk setiap tenaga kerja dalam satu tahun. Sedangkan tingkat upah industri tembakau olahan hanya mencapai 0,10 juta rupiah per tahun untuk setiap tenaga kerja. Sektor industri pengolahan tembakau memiliki tingkat upah yang masih rendah yang menunjukkan bahwa tingkat kesejahteraan tenaga kerja pada sektor ini masih rendah.

Koefisien tenaga kerja pada sektor pertanian tembakau menunjukkan angka 0,17 yang berarti bahwa untuk menghasilkan output senilai Rp100, sektor pertanian memerlukan tenaga kerja sebanyak 17 orang. Koefisien tenaga kerja pada sektor industri rokok menunjukkan angka yang lebih kecil bila dibandingkan dengan sektor industri tembakau olahan. Koefisen tenaga kerja sektor industri rokok adalah sebesar 0,0024 sedangkan pada industri tembakau olahan adalah 0,0624 . Hal ini menunjukkan bahwa untuk menghasilkan output sebesar 1000 rupiah, sektor ini hanya membutuhkan tenaga kerja sebanyak 2 orang, sedangkan untuk menciptakan output yang sama nilainya, yakni 1000 rupiah, sektor tembakau olahan membutuhkan tenaga kerja sebanyak 62 orang.

\subsection{Analisis Keterkaitan Industri Pengolahan Tembakau Dengan Sektor Perekonomian Lain}

Peran sektor pertanian tembakau dan industri pengolahan tembakau dilihat dari kaitannya dengan sektor perekonomian lain di Kabupaten Ponorogo. Keterkaitan sektor-sektor tersebut dilihat dari bagaimana keterkaitan ke depan dan ke belakang sektor.

Sektor tembakau memiliki keterkaitan langsung ke depan paling besar dengan sektor tembakau olahan, yakni dengan nilai 0,511. Selain itu, sektor ini juga memiliki keterkaitan langsung ke depan dengan sektor pertanian tembakau itu sendiri dan industri rokok dengan nilai KLD 0,038 dan 0,002 seperti ditunjukkan pada Tabel 3.

Tabel 3. juga menunjukkan bahwa industri rokok memiliki keterkaitan langsung ke depan paling besar dengan industri rokok itu sendiri dengan nilai KLD 0,002. Hal ini berarti bahwa adanya peningkatan permintaan akhir pada industri rokok paling besar hanya berpengaruh pada industri itu sendiri. Kaitan dengan sektor hilir industri rokok yang lain paling besar adalah pada sektor hotel dan restoran serta usaha 
bangunan dan jasa perusahaan. Sementara itu, industri tembakau olahan memiliki nilai keterkaitan langsung ke depan paling besar dengan industri rokok dengan nilai KLD 0,027. Sektor hilir yang lain yang berkaitan dengan industri ini adalah industri tembakau olahan itu sendiri dan industri kimia.

Tabel 3. Peringkat tiga terbesar keterkaitan langsung ke depan sektor tembakau, rokok, dan tembakau olahan (Tabel IO Ponorogo, 2011 derivasi Tabel IO Jatim, 2011)

\begin{tabular}{|c|c|c|c|c|}
\hline Sektor & $\begin{array}{l}\text { Total } \\
\text { KLD }\end{array}$ & Peringkat & Sektor & KLD \\
\hline \multirow{3}{*}{ Tembakau } & \multirow{3}{*}{0,550} & 1 & $\begin{array}{c}\text { Tembakau } \\
\text { olahan }\end{array}$ & 0,511 \\
\hline & & 2 & Tembakau & 0,038 \\
\hline & & 3 & Rokok & 0,002 \\
\hline \multirow{3}{*}{ Rokok } & \multirow{3}{*}{0,003} & 1 & $\begin{array}{c}\text { Rokok } \\
\text { Hotel dan }\end{array}$ & 0,002 \\
\hline & & $\begin{array}{l}2 \\
3\end{array}$ & Restoran & 0,001 \\
\hline & & & $\begin{array}{l}\text { Bangunan } \\
\text { dan Jasa } \\
\text { Perusahaan }\end{array}$ & \\
\hline \multirow{3}{*}{$\begin{array}{c}\text { Tembakau } \\
\text { Olahan }\end{array}$} & \multirow{3}{*}{0,032} & 1 & Rokok & 0,027 \\
\hline & & 2 & $\begin{array}{c}\text { Tembakau } \\
\text { olahan } \\
\text { Industri }\end{array}$ & 0,005 \\
\hline & & 3 & Kimia & 0,000 \\
\hline
\end{tabular}

Tabel 4. Peringkat Tiga Terbesar Keterkaitan Langsung Ke Belakang Sektor Tembakau, Rokok, dan Tembakau Olahan (IO Ponorogo JATIM, 2011)

\begin{tabular}{|c|c|c|c|c|}
\hline Sektor & $\begin{array}{l}\text { Total } \\
\text { KLB }\end{array}$ & Peringkat & Sektor & KLB \\
\hline \multirow{7}{*}{ Tembakau } & \multirow{7}{*}{0,152} & 1 & Tembakau & 0,038 \\
\hline & & 2 & Usaha & 0,032 \\
\hline & & & Bangunan & \\
\hline & & & dan Jasa & \\
\hline & & & $\begin{array}{l}\text { Perusahaan } \\
\text { Industri }\end{array}$ & \\
\hline & & & Pupuk dan & \\
\hline & & 3 & Pestisida & 0,027 \\
\hline \multirow{4}{*}{ Rokok } & \multirow{4}{*}{0,164} & 1 & Perdagangan & 0,040 \\
\hline & & & $\begin{array}{l}\text { Industri } \\
\text { tembakau }\end{array}$ & \\
\hline & & 2 & olahan & 0,027 \\
\hline & & 3 & Cengkeh & 0,023 \\
\hline \multirow{4}{*}{$\begin{array}{c}\text { Tembakau } \\
\text { Olahan }\end{array}$} & \multirow{4}{*}{0,660} & 1 & Tembakau & 0,511 \\
\hline & & 2 & Perdagangan & 0,110 \\
\hline & & & Angkutan & \\
\hline & & 3 & Darat & 0,015 \\
\hline
\end{tabular}

Analisis keterkaitan ke belakang menunjukkan bahwa industri rokok memiliki keterkaitan langsung ke belakang paling besar dengan sektor perdagangan dengan nilai KLB mencapai 0,040. Keterkaitan sektor ini pada sektor hulunya yang lain adalah pada sektor tembakau olahan dan pertanian cengkeh. Sementara itu, industri tembakau olahan memiliki keterkaitan langsung ke belakang paling besar dengan sektor pertanian tembakau, sektor perdagangan dan angkutan darat.

Selain dilakukan analisis keterkaitan, juga dilakukan analisis dampak penyebaran. Konsep analisis dampak penyebaran terdiri dari analisis koefisien penyebaran dan kepekaan penyebaran.

Koefisien penyebaran dapat dikatakan sebagai kemampuan suatu sektor untuk menarik sektor hulunya (Yusri, 2007).

Tabel 5. Koefisien Penyebaran Beberapa Sektor Perekonomian Kabupaten Ponorogo Tahun 2011 (IO Ponorogo JATIM, 2011)

\begin{tabular}{lcc}
\hline \multicolumn{1}{c}{ Sektor } & $\begin{array}{c}\text { Koefisien } \\
\text { Penyebaran }\end{array}$ & Peringkat \\
\hline $\begin{array}{l}\text { Industri pengolahan susu } \\
\text { dan produk dari susu }\end{array}$ & 1,484212 & 1 \\
Pakan Ternak & 1,482368 & 2 \\
Tembakau Olahan & 1,287921 & 5 \\
Industri Kertas dan & & \\
Barang Cetakan & 0,953992 & 32 \\
Rokok & 0,878416 & 47 \\
Tembakau & 0,859764 & 51 \\
Cengkeh & 0,854036 & 54 \\
\hline
\end{tabular}

Tabel 5. menunjukkan bahwa nilai koefisien penyebaran sektor tembakau olahan bernilai lebih dari satu, yakni 1,287921. Hal tersebut menunjukkan bahwa sektor industri tembakau olahan memiliki kemampuan kuat untuk menarik pertumbuhan output sektor hulunya. Nilai koefisien penyebaran lebih dari satu menunjukkan bahwa sektor industri tembakau olahan adalah sektor yang sensitif terhadap pengaruh pertumbuhan ekonomi di Kabupaten Ponorogo dan memiliki ketergantungan yang tinggi terhadap sekor lain.

Sektor industri rokok dan pertanian tembakau memiliki nilai koefisien penyebaran kurang dari satu. Sektor industri rokok memiliki nilai koefisien penyebaran sebesar 0,878416, sedangkan sektor pertanian tembakau 0,859764 . Sehingga dapat dikatakan bahwa sektor industri rokok dan sektor pertanian tembakau di Kabupaten Ponorogo memiliki kemampuan yang 
lemah untuk menarik pertumbuhan output sektor hulunya.

Sementara itu, kepekaan penyebaran
adalah konsep untuk menggambarkan
kemampuan suatu sektor perekonomian dalam
mendorong pertumbuhan sektor perekonomian
hilirnya. Nilai kepekaan penyebaran lebih dari
satu menunjukkan sektor perekonomian tersebut
memiliki kemampuan yang kuat untuk
mendorong pertumbuhan sektor hilirnya.

Tabel 6. Kepekaan Penyebaran Beberapa Sektor Perekonomian Kabupaten Ponorogo Tahun 2011 (IO Ponorogo JATIM, 2011)

\begin{tabular}{lcc}
\hline \multicolumn{1}{c}{ Sektor } & $\begin{array}{c}\text { Kepekaan } \\
\text { Penyebaran }\end{array}$ & Peringkat \\
\hline $\begin{array}{l}\text { Perdagangan } \\
\text { Usaha Bangunan dan }\end{array}$ & 4,07423 & 1 \\
Jasa Perusahaan & 1,65750 & 2 \\
Tembakau & 1,13717 & 14 \\
Industri Kertas dan & & \\
Barang Cetakan & 1,00263 & 20 \\
Tembakau Olahan & 0,73901 & 54 \\
Cengkeh & 0,73273 & 57 \\
Rokok & 0,71794 & 64 \\
\hline
\end{tabular}

Tabel 6. menunjukkan bahwa sektor pertanian tembakau memiliki nilai kepekaan penyebaran lebih besar dari satu, yakni 1,13683. Hal ini menunjukkan bahwa sektor pertanian tembakau adalah sektor yang mampu mendorong pertumbuhan output sektor hilirnya. Sektor industri tembakau olahan dan industri rokok ternyata memiliki nilai kepekaan penyebaran kurang dari satu. Nilai kepekaan penyebaran industri tembakau olahan dan industri rokok masing-masing adalah 0,73879 dan 0,71772 . Hal tersebut menunjukkan bahwa industri rokok dan tembakau olahan kurang mampu untuk mendorong pertumbuhan sektor hilirnya berupa peningkatan output.

\subsection{Dampak Aktivitas Ekonomi Industri Pengolahan Tembakau Terhadap Sektor-Sektor Perekonomian Lain di Kabupaten Ponorogo}

Pengganda output adalah nilai total output atau nilai produksi yang dihasilkan oleh sektor pertanian tembakau, industri rokok, dan industri tembakau olahan untuk memenuhi adanya perubahan satu unit permintaan akhir. Industri tembakau olahan memiliki angka pengganda output sebesar 1,7993 dan menduduki peringkat ke-5 dari keseluruhan sektor perekonomian. Hal ini menunjukkan bahwa peningkatan satu satuan permintaan akhir sektor tembakau olahan akan meningkatkan output keseluruhan sektor perekonomian sebesar 1,7993 satuan. Sektor industri rokok memiliki angka pengganda output senilai 1,2272 dengan berada pada peringkat ke47. Sementara itu, sektor pertanian tembakau memiliki nilai pengganda output yang lebih kecil, yakni 1,2011. Hasil analisis angka pengganda output menunjukkan bahwa sektor industri tembakau olahan memiliki peran yang lebih besar. Artinya peningkatan permintaan akhir sektor tembakau olahan akan lebih banyak memberikan pengaruh pada peningkatan output sektor perekonomian lain di Kabupaten Ponorogo.

Pada analisis angka pengganda pendapatan, pendapatan yang dimaksud adalah pendapatan yang dihasilkan oleh rumah tangga sebagai balas jasa kegiatan produksi berupa upah dan gaji. Sektor industri tembakau olahan memiliki nilai pengganda pendapatan tertinggi. Angka pengganda sektor ini mencapai 14,5607 yang berarti peningkatan satu satuan permintaan akhir industri tembakau olahan akan meningkatkan pendapatan rumah tangga di seluruh sektor perekonomian sebesar 14,5607 satuan. Industri rokok menempati peringkat ke32 dengan nilai pengganda pendapatan 1,33569. Sementara itu, sektor pertanian tembakau menunjukkan angka pengganda pendapatan yang tidak terlalu besar, yakni 1,13798 dan berada pada peringkat ke-52. Nilai pengganda pendapatan sektor tembakau olahan menunjukkan bahwa sektor tersebut memiliki peran yang lebih besar dalam peningkatan pendapatan masyarakat pada keseluruhan sektor perekonomian dibandingkan dengan sektor tembakau dan industri rokok.

Pengganda tenaga kerja merupakan efek total perubahan lapangan kerja pada suatu perekonomian akibat perubahan satu satuan permintaan akhir pada suatu sektor. Pengganda tenaga kerja mengukur jumlah tenaga kerja yang mampu terserap oleh keseluruhan sektor perekonomian akibat peningkatan permintaan akhir suatu sektor sebesar satu satuan (Fahriyah, 2006). Nilai pengganda tenaga kerja sektor industri rokok lebih tinggi jika dibandingkan dengan sektor pertanian tembakau dan tembakau olahan. Pengganda tenaga kerja sektor industri rokok mencapai 1,91633 yang berarti bahwa apabila terjadi peningkatan output akibat menngkatnya permintaan akhir sektor industri rokok sebesar satu satuan, akan meningkatkan 
penyerapan tenaga kerja pada keseluruhan sektor perekonomian sebanyak 2 orang tenaga kerja $(1,916)$ baik secara langsung maupun tidak langsung. Sektor pertanian tembakau dan industri tembakau olahan memiliki nilai pengganda tenaga kerja yang lebih kecil. Masing-masing nilai pengganda tenaga kerja sektor ini adalah 1,50177 untuk sektor pertanian tembakau dan 1,13523 untuk sektor industri tembakau olahan. Nilai pengganda tenaga kerja sektor industri rokok yang lebih besar dibandingkan dengan sektor pertanian tembakau dan industri tembakau olahan menunjukkan bahwa sektor industri rokok mampu menciptakan dampak penyerapan tenaga kerja yang relatif besar pada seluruh sektor perekonomian yang ada.

\subsection{Penyerapan Tenaga Kerja Industri Pengolahan Tembakau}

Penyerapan tenaga kerja industri pengolahan tembakau, yakni industri rokok dan tembakau olahan dianalisis dengan konsep ILOR (Incremental Labor Output Ratio). ILOR dapat diinterpretasikan sebagai suatu ukuran yang menggambarkan banyaknya lapangan kerja baru yang dapat diciptakan dengan penambahan output produksi pada suatu sektor perekonomian (BPS, 2014). Hasil perhitungan nilai ILOR menunjukkan bahwa sektor pertanian tembakau memiliki nilai ILOR positif, sedangkan industri rokok dan industri tembakau olahan memiliki nilai ILOR nol, seperti ditunjukkan pada Tabel 7.

Tabel 7. Nilai ILOR Beberapa Sektor Perekonomian Kabupaten Ponorogo 2012

\begin{tabular}{lc}
\hline \multicolumn{1}{c}{ Sektor } & ILOR 2012 \\
\hline Tembakau & 0,04063 \\
Rokok & 0,00000 \\
Tembakau Olahan & 0,00000 \\
\hline
\end{tabular}

Tabel 7. menunjukkan bahwa nilai ILOR sektor pertanian tembakau sebesar 0,04063 menunjukkan bahwa penambahan output PDRB sebesar 100 juta rupiah pada sektor tembakau akan mampu menyerap 4 orang tenaga kerja setiap tahunnya. Hal ini sesuai apabila dilihat dari kondisi pertanian tembakau di Kabupaten Ponorogo yang produksinya mengalami peningkatan seiring dengan adanya peningkatan luas lahan. Dengan demikian, semakin meningkat output sektor pertanian tembakau, maka penyerapan tenaga kerja juga semakin meningkat karena sifatnya yang padat tenaga. Sementara itu ILOR sektor industri rokok dan tembakau olahan adalah nol. Adanya peningkatan output sektor industri rokok maupun tembakau olahan ternyata tidak mampu meningkatkan penyerapan tenaga kerja. ILOR bernilai nol tersebut mengindikasikan adanya peningkatan produktivitas tenaga kerja atau penggunaan teknologi.

\section{Kesimpulan}

Kesimpulan dalam penelitian ini adalah sebagai berikut: 1) Industri rokok memiliki kontribusi relatif besar pada struktur permintaan dan ouput senilai Rp526.061,63 juta (peringkat ke-6.) dan pembentukan ekspor pada peringkat ke-1 (Rp104.143,42 juta). Sementara itu, kontribusi industri tembakau olahan dalam struktur permintaan, output, nilai tambah bruto, ekspor-impor, ataupun tenaga kerja cenderung kecil. 2) Analisis koefisien penyebaran menunjukkan bahwa sektor tembakau olahan berperan dalam menarik sektor hulunya yakni pertanian tembakau dengan nilai koefisien sebesar 1,28748. Sementara itu, nilai kepekaan penyebaran industri tembakau olahan dan industri rokok masing-masing 0,73901 dan 0,71794 tergolong rendah yang menunjukkan bahwa kemampuan industri rokok dan tembakau olahan dalam mendorong sektor hilirnya rendah. 3) Sektor tembakau olahan memiliki dampak pengganda relatif besar untuk meningkatkan output dan pendapatan rumah tangga di seluruh sektor perekonomian Kabupaten Ponorogo. Sementara itu, industri rokok memiliki dampak pengganda relatif besar untuk meningkatkan penyerapan tenaga kerja sebesar 1,91633. 4) Hasil perhitungan Incremental Labor Output Ratio (ILOR) industri rokok dan tembakau olahan menunjukkan nilai nol. Hal ini menunjukkan bahwa adanya penambahan output pada sektor tersebut tidak menyebabkan peningkatan ataupun penurunan penyerapan tenaga kerja karena sektor industri lebih bersifat padat modal.

\section{Daftar Pustaka}

[1]. Astuti, K. \& Handoko, B.S., 2007. Analisis Pertumbuhan Ekonomi, Kebutuhan Investasi, dan Penyerapan Tenaga Kerja di Kabupaten Sleman. Jurnal Ekonomi dan Bisnis, 1(3), pp.161-173.

[2]. Badan Perencanaan Pembangunan Daerah. 2013. Ponorogo dalam Angka, Ponorogo. 
[3]. Badan Pusat Statistik. 2014. Incremental Labor Output Ratio. Available at : http://bps.go.id/int/index.php/indikator/73 $\& s a=U \&$ ei=6U. Diakses pada 12 Maret 2014.

[4]. Fahriyah. 2006. Kajian Kelembagaan dan Dampak Penerapan Otonomi Daerah Terhadap Kinerja Industri Gula di Kabupaten Pasuruan. Institut Pertanian Bogor.

[5]. Hadi, P.U. \& Friyatno, S. 2008. Peranan Sektor Tembakau Dan Industri Rokok Dalam Perekonomian Indonesia: Analisis Tabel I -O Tahun 2000. Jurnal Agro Ekonomi, 26(1), pp.90-121. Available at: http://pse.litbang.deptan. go.id/ind/pdffiles/JAE 26-1e.

[6]. Miller, R.. \& Blair, P.., 1985. Input-Output Analysis: Foundations and Extensions, Englewood Cliffs. Prentice-Hall Inc : New Jersey.

[7]. Miradani, S.D., 2010. Analisis Perencanaan Pembangunan Agroindustri Provinsi Jawa Timur: Pendekatan Sektoral dan Regional. Majalah Ekonomi, (2), pp.119-135.

[8]. Nazara, S. 2005. Analisis Input-Output P. Rahardja, ed., Lembaga Penerbit Fakultas Ekonomi Universitas Indonesia. Jakarta.

[9]. Ningsih, R. 2001. Peranan Industri Kayu Lapis dalam Perekonomian Provinsi Jambi : Analisis Input-Output. Tesis. Institut Pertanian Bogor. Bogor.

[10]. Tobacco Control Support Center. 2012. Buku Fakta Tembakau. Tobacco Control Support Center - Ikatan Ahli Kesehatan Masyarakat Indonesia. Jakarta. 